\title{
Effects of Lemon Balm on the Oxidative Stability and the Quality Properties of Hamburger Patties during Refrigerated Storage
}

\author{
Hyun-Joo Lee ${ }^{1}$, You-Jung Choi, Yang-II Choi ${ }^{2}$, and Jae-Joon Lee* \\ Department of Food and Nutrition, Chosun University, Gwangju 500-759, Korea \\ ${ }^{1}$ Department of Nutrition and Culinary Science, Hankyong National University, Ansung 56-749, Korea \\ ${ }^{2}$ Department of Animal Science, Chungbuk National University, Cheongju 361-763, Korea
}

\begin{abstract}
This study was performed to investigate the effects of lemon balm (Melissa officinalis L.) on various quality and antioxidant activity of hamburger patties. Lemon balm extract (LBE) showed the highest amount of total polyphenol $(801.00 \mathrm{mg}$ TAE/g DW) and flavonoids (65.05 mg RA/g DW). The $\mathrm{IC}_{50}$ value of DPPH hydroxyl scavenging of LBE was $132 \mu \mathrm{g} / \mathrm{mL}$. The hamburger patties were prepared by $0 \%(\mathrm{~N}), 0.1 \%(\mathrm{~L} 1), 0.5 \%(\mathrm{~L} 2)$, and $1.0 \%(\mathrm{~L} 3)$ of the lemon balm powder. The addition of lemon balm powder increased the chewiness value, but did not affect the hardness, cohesiveness, and springiness values. Lemon balm powder had positive effects on sensory evaluation of patties. The $\mathrm{pH}$ of all patties decreased with longer storage period. 2-Thiobarbituric acid value, volatile basic nitrogen content, and the total microbial counts of hamburger patties in the L3 group were lower, compared to those of the normal (N group). In conclusion, the L3 group had significantly delayed lipid peroxidation compared to other treatment groups. However, the addition of lemon balm powder into patties showed no significantly influence on proximate composition, calorie contents, water holding capacity and cooking loss of patties. Therefore, lemon balm might be a useful natural antioxidant additive in meat products.
\end{abstract}

Keywords: lemon balm, hamburger patty, thiobarbituric acid value, antioxidant effect, quality

\section{Introduction}

Modernized society has led to a lot of changes in the structure and style of dietary habits, along with qualitative improvements of daily life, concomitant with advances in technology and the information industry. Food consumption patterns have been gentrified and diversified due to changes in nuclear family dynamics, the increase of women entering public affairs, the development of the food service industry, and the westernization of food culture, and there have been increases in the use of convenience food, processed food, fast food, and ready-to-eat food due to their convenience. In particular, the preference and consumption of fast food, such as hamburgers and pizza, has extended from youths to middle-aged and elderly adults (Choi et al., 2013; Oh and Lim, 2011; Song et al., 2000).

The hamburger, which is a prototypical fast food, is

\footnotetext{
*Corresponding author: Jae-Joon Lee, Department of Food and Nutrition, Chosun University, Gwangju 501-759, Korea. Tel: +82-62-230-7722, Fax: +82-62-225-7726, E-mail: leejj80@ chosun.ac.kr
}

made by inserting a cooked patty composed of pulverized livestock meat between breads. Hamburger patties use mostly beef, pork, or chicken as the main materials, and about $20-30 \%$ animal fat is added (Miller et al., 1987), or it is made using the meat containing attached fat (Cross et al., 1980). With meat products prepared using livestock meat such as the hamburger patty, a warmed-over flavor (WOF) due to lipid oxidation during processing and storing is generated, and the quality can be deteriorated (Murphy et al., 1998). This WOF is generated more rapidly in cooked meat products and ground meat than in uncooked meat products (El-Alim et al., 1999). In the grinding process of livestock meat, the cell walls of muscle are destroyed, and rapid degradation via interactions of pro-oxidant substances such as unsaturated fatty acid and non-heme occurs, and lipid oxidation is promoted (Tichivangana and Morrisey, 1985). Additionally, oxidative products, such as various types of alcohols, aldehydes, and ketones, generated by the oxidation impair DNA in vivo may even cause cancer, and this is also related to cellular aging (Mukai and Goldstein, 1976; Shamberger et al., 1974; Shamberger et al., 1977). The palatability of meat products has been improved, and phenolic synthetic 
antioxidants have been widely used (Garacía-Íñiguez de Ciriano et al., 2010; Hernández-Hernández et al., 2009; Kong et al., 2010; Lara et al., 2011). However, their use is being limited because of safety concerns (Barnen, 1975). As a result, studies on natural antioxidants to replace synthetic antioxidants have been actively conducted, and there have been attempts to develop hamburger patties and meat products that have better health properties, as well as quality and storage improvement by adding natural functional materials having antioxidant and antibacterial effects (Jung et al., 2004; Lara et al., 2011; McCarthy et al., 2001; Park et al., 2011).

Lemon balm (Melissa officinalis L.) is an herb with fresh, sweet, and strong lemon flavoring. It is a perennial plant of Tubiflorae, lamiaceae and is also a famous bee plant. From ancient times, in the West, dried lemon balm leaves have been used often as valuable spices and herbs. Lemon balm flavors induce calm and comfortable feelings and act to lower blood pressure by lowering the heartbeat (Dastmalchi et al., 2008; Lamaison et al., 1990). Additionally, lemon balm has been used to treat diseases such as depression, anxiety headaches, memory deterioration, and menstrual pain. It has also been used as an antidote for detoxifying poisonous mushroom. Dried lemon balm extract has been used to improve blood circulation. Antibacterial, anti-hormonal, antioxidant, and antiviral activities have also been reported (Gruenwalkd et al., 2000; Sweetman, 2002; Yang et al., 2009). For these reasons, lemon balm is a good potential source of functional components, including polyphenolic compounds (rosmarinic acid, caffeic acid, and protocatechuic acid), flavonoids (luteolin), monoterpenoid aldehydes, essential oils (citral), sesquiterpenes, and tannins (Jang et al., 2011; Lamaison et al., 1990). Therefore, many studies have investigated the use of lemon balm as natural antioxidants in food products (Berasategi et al., 2011; Garacía-Íñiguez de Ciriano et al., 2010; Lara et al., 2011).

The objective of the this study was to investigate the effects of addition of different levels of lemon balm to hamburger patties on retarding lipid oxidation as well as evaluating the various quality parameters during storage at $4^{\circ} \mathrm{C}$.

\section{Materials and Methods}

\section{Sample preparation}

The lemon balm used in experiments was purchased from Muan herb botanic garden (Muan herb farm, Korea) in August 2012. The moisture was removed by using the salad spinner (Caous, WINDAX, Korea) after wa- shing 2 times. The lemon balm was dried using a lyophilizer (ED 8512, Ilshin, Korea), triturated using a grinder (HR 2904, Philips Co., Netherlands), and then was stored until used for experiments in a deep freezer at $-70^{\circ} \mathrm{C}$. Fresh beef and pork muscles were purchased in a local market. All fat and visible connective tissue were removed from the fresh pork muscles.

\section{Sample extraction}

One hundred grams of lemon balm was added to $1.5 \mathrm{~L}$ of $80 \%$ ethanol, and then, it was extracted 3 times for $3 \mathrm{~h}$ in a $65^{\circ} \mathrm{C}$ heating mantle (Mtops ms-265, Korea) with a reflux cooler and filtered with qualitative filter paper (No. 2, Advantec, Japan). Solvent was removed from the remainder of the sample in a $40^{\circ} \mathrm{C}$ water bath with rotary vacuum evaporator (EYELA VACUUM NVC-1100, Japan). After that, it was decompressed, concentrated, lyophilized, and stored until use in a $-70^{\circ} \mathrm{C}$ deep freezer.

\section{Assay of total polyphenol content}

The analysis of total polyphenol content was performed according to the slightly modified method of Folin-Denis (1912). Briefly, a sample aliquot of $1 \mathrm{~mL}$ extract (1 mg/ $\mathrm{mL}$ of distilled water) and $2 \mathrm{~mL}$ of Folin reagent were put into a test tube and allowed to stand for $3 \mathrm{~min}$ at room temperature, and then, $2 \mathrm{~mL}$ of $10 \% \mathrm{Na}_{2} \mathrm{CO}_{3}$ was added into that test tube. The solution in the tube was thoroughly mixed and allowed to stand for $40 \mathrm{~min}$ at $30^{\circ} \mathrm{C}$, and the absorbance of the solution was measured at 760 $\mathrm{nm}$ using a UV-spectrophotometer (Shimadzu UV-1601 PC, Japan). The standard curve was plotted from samples with a final concentration of $0,0.2,0.4,0.6,0.8$, and 1.0 $\mathrm{mg} / \mathrm{mL}$ using tannic acid, and total polyphenol content of the sample was obtained from this calibration curve. The results were expressed as $\mathrm{mg}$ of tannic acid equivalent (TAE) per gram dry weight (DW).

\section{Assay of total flavonoid content}

Total flavonoids were measured according to the Davis method with slight modifications (Chae et al., 2002). Briefly, a sample aliquot of $1 \mathrm{~mL}$ extract $(1 \mathrm{mg} / \mathrm{mL}$ of distilled water) and $2 \mathrm{~mL}$ of diethylene glycol were added to a test tube, and then $20 \mu \mathrm{L}$ of $1 \mathrm{~N} \mathrm{NaOH}$ was added into that test tube. The solution in the tube was incubated for $1 \mathrm{~h}$ in a $30^{\circ} \mathrm{C}$ water bath, and the absorbance of the solution was measured at $420 \mathrm{~nm}$ using a UV-spectrophotometer (Shimadzu UV-1601PC, Japan). The standard curve was plotted from samples with a final concentration 
of $0,0.2,0.4,0.6,0.8$, and $1.0 \mathrm{mg} / \mathrm{mL}$ using rutin, and total flavonoid content of the sample was obtained from this calibration curve. The results were expressed as mg of rutin equivalent (RE) per gram DW.

\section{1,1-Diphenyl-2-picrylhydrazyl (DPPH) radical sca- venging activity}

DPPH radical scavenging activity of lemon balm ethanol extract was determined according to the modified method described by Blois (1958). Briefly, $1 \mathrm{~mL}$ of lemon balm ethanol extract and $1 \mathrm{~mL}$ of $0.2 \mathrm{mM}$ DPPH were added to a test tube and mixed for $30 \mathrm{~min}$ at $37^{\circ} \mathrm{C}$, and the absorbance of the mixture was measured at $517 \mathrm{~nm}$ using a UV-spectrophotometer (Shimadzu UV-1601PC, Japan). At the same time, antioxidant activity was measured by the same method using ascorbic acid (Sigma Co., USA), which is a natural antioxidant, as well as butylated hydroxyanisole (BHA) and butylated hydroxytoluene (BHT), which are synthetic antioxidants, as a positive control groups. The DPPH radical scavenging activity of each sample was calculated using the following formula: (absorbance of sample addition group/absorbance of the control group) $\times 100$. BHA, BHT and ascorbic acid were used at $0.5 \mathrm{mg} / \mathrm{mL}$. Sample concentration providing $50 \%$ inhibition $\left(\mathrm{IC}_{50}\right)$ was calculated from the graph of inhibition percentage against sample concentration.

\section{Antioxidant index measurement}

The antioxidant index was measured using Rancimat (Metrohm Model 679, Switzerland) according to the method of Joo and Kim (2002). The lemon balm ethanol extract was added in soybean oil (Sigma Co., USA) so that the content, completely removing the solvent in them, became $1 \mathrm{mg} / \mathrm{mL}$, and then the extract and fat of the sample were mixed well using an ultrasonic processor (UCX750, USA). For Rancimat measurement conditions, $3.0 \mathrm{~g}$ of lemon balm ethanol extract was put into a reaction vessel and added to $70 \mathrm{~mL}$ of distilled water, and the oxidation stability was compared with an air flow rate of $20 \mathrm{~L} /$ $\mathrm{h}$ at $110^{\circ} \mathrm{C}$. All measurements were presented as the average value of the values obtained from experiments repeated three times. BHA and BHT, which are synthetic antioxidants, and ascorbic acid, which is a natural antioxidant, were added to soybean oil, and they were compared as positive controls.

\section{Preparation of hamburger patties}

The manufacture of the hamburger patty with the addition of lemon balm powder was performed in a prelimi-
Table 1. Formula of patties added with lemon balm powder (\%)

\begin{tabular}{cccccc}
\hline \hline \multirow{2}{*}{ Ingredients } & \multicolumn{5}{c}{ Treatment $^{\mathrm{I})}$} \\
\cline { 2 - 6 } & $\mathrm{N}$ & $\mathrm{C}$ & $\mathrm{L} 1$ & $\mathrm{~L} 2$ & $\mathrm{~L} 3$ \\
\hline Beef & 70.0 & 70.0 & 70.0 & 70.0 & 70.0 \\
Pork & 10.0 & 10.0 & 10.0 & 10.0 & 10.0 \\
Soybean oil & 3.0 & 3.0 & 3.0 & 3.0 & 3.0 \\
Onion & 5.0 & 5.0 & 5.0 & 5.0 & 5.0 \\
Garlic & 2.0 & 2.0 & 2.0 & 2.0 & 2.0 \\
Bread powder & 5.3 & 5.3 & 5.3 & 5.3 & 5.3 \\
Egg & 3.0 & 3.0 & 3.0 & 3.0 & 3.0 \\
Salt & 1.5 & 1.5 & 1.5 & 1.5 & 1.5 \\
Black pepper & 0.2 & 0.2 & 0.2 & 0.2 & 0.2 \\
\hline Total & 100.0 & 100.0 & 100.0 & 100.0 & 100.0 \\
\hline Ascorbic acid & - & 0.05 & - & - & - \\
Lemon balm powder & - & - & 0.1 & 0.5 & 1.0 \\
\hline
\end{tabular}

${ }^{1)} \mathrm{N}$ (Normal: no lemon balm powder added), $\mathrm{C}$ (Control: ascorbic acid $0.05 \%$ added), L1 (lemon balm powder $0.1 \%$ added), L2 (lemon balm powder $0.5 \%$ added), L3 (lemon balm powder $1.0 \%$ added).

nary experiment by referring to the study of Oh and Lim (2011) and the previous study of Lee and Cho (2012), and the mixing ratios of the materials used in the hamburger patties are listed in Table 1 . The beef and pork meat were ground using a meat chopper (M-12S, Hankook Fujee Industries Co., Korea), on which the holes plate of 8-mm diameter were mounted after removing the connective tissue and excess fat. The samples with ground onion, garlic, bread crumbs, cooking oil, egg, salt, and pepper were mixed in with the ground beef and pork were in the normal group. The treatment groups with added $0.1 \%, 0.5 \%$, and $1 \%$ lemon balm powder were noted as L1, L2, and L3. Ascorbic acid, which is widely used as an antioxidant in processed foods, was used as a positive control group and the $0.05 \%$ concentration of ascorbic acid was selected on the basis of previous studies (Choi et al., 2011). Each $100 \mathrm{~g}$ mixture was molded in a shape with a diameter of $10.0 \mathrm{~cm}$ and thickness of $1.2 \mathrm{~cm}$ using a patty molding machine, and this experiment was performed by opening a package of patties from each experimental group on $0,5,10$, and $15 \mathrm{~d}$, while storing the patties for $15 \mathrm{~d}$ in vacuum-sealed packaging (FJ-500XL, Fugee Tech, Korea) using unheated nylon/PE film in the refrigerator. The sample analysis of each experimental item was performed in triplicate.

\section{Proximate composition}

The analysis of proximate composition of sample was conducted in accordance with Association of Official Analytical Chemists (AOAC) method (1990), and moisture 
was analyzed by drying using heat at atmospheric pressure and $105^{\circ} \mathrm{C}$. Crude protein was analyzed using the micro-Kjeldahl method, crude fat was analyzed using the Soxhlet extraction method, crude ash was analyzed using the ashing method, and calories were analyzed using a calorimeter (PARR 1351 Bomb Caloriemeter, USA).

\section{Measurement of water holding capacity (WHC)}

The measurement of WHC was performed in accordance with the method of Laakkonen et al. (1970). A 12$\mathrm{mL}$ tube with fine holes, the sample of $0.5 \pm 0.05 \mathrm{~g}$, and the combined weight of the sample and tube were measured individually. The sample was heated for $20 \mathrm{~min}$ in an $80^{\circ} \mathrm{C}$ water bath (HB-205SW, Hanbaek Scientific Co., Korea), and the ratio (\%) of the sample weight after heating to that before heating was calculated, after cooling at room temperature for $10 \mathrm{~min}$ and centrifuging at $4^{\circ} \mathrm{C}$ at $6,710 \mathrm{~g}$ for $10 \mathrm{~min}$.

\section{Measurement of cooking loss}

To examine cooking loss, the samples were preheated on an open flame for $3 \mathrm{sec}$ using a home pan, and a hamburger patty was inserted into each sample and heated until the temperature in the center of the patty reached $72^{\circ} \mathrm{C}$. Then, further heat treatment was conducted for 15 $\mathrm{min}$. The samples were transferred in a wire net, and then the weights of the samples were measured after cooling for $30 \mathrm{~min}$. The weights of patties before and after the heat treatment measured and then the reduced weight was expressed as the cooking loss (\%).

\section{Texture profile analysis}

The texture properties of each cooked hamburger patty were measured by the Rheometer (Compac-100, Sun Scientific Co., Japan) and analyzed using Rheology Data System version 2.01. When measuring the test items above, the table speed was $110 \mathrm{~mm} / \mathrm{min}$, the graph interval was $20 \mathrm{~m} / \mathrm{s}$, and the load cell (max) was $10 \mathrm{~kg}$. The texture properties of sample were expressed as hardness (g), cohesiveness, springiness, and chewiness (g).

\section{Sensory evaluation}

After explaining the rules, sensory evaluation was conducted using a group consisting of ten students with foodrelated majors and graduate students who were already knowledgeable about the sensory test. The color, springiness, flavor, juiciness, and overall acceptability were evaluated on a 5-point scale, with "extremely like" being a 5, "moderately like" being a 3 , and "extremely dislike" being a 1 point, with respect to each evaluation item. The sample was heated and cooked until the center temperature of hamburger patty reached $72^{\circ} \mathrm{C}$ by pan-frying, and then it was tested on a white dish after cutting it into $2 \mathrm{~cm} \times 2 \mathrm{~cm}$ $\times 1.5 \mathrm{~cm}$ pieces. Drinking water was provided between each sample.

\section{Determination of $\mathbf{p H}$}

The $\mathrm{pH}$ values of meat patties were assessed according to the Khalil method (2000). Briefly, $10 \mathrm{~g}$ of sample was homogenized for $30 \mathrm{sec}$ using a stomacher (400 Lab blender, Seward, England) in $100 \mathrm{~mL}$ of distilled water. Then, the $\mathrm{pH}$ of sample was measured by $\mathrm{pH}-$-meter (WTW $\mathrm{pH}$ 720 , Germany).

\section{2-Thiobarbituric acid (TBA) value}

The TBA values were measured according to the modified extraction method described by Witte et al., (1970). Briefly, $10 \mathrm{~g}$ of each sample, $15 \mathrm{~mL}$ of cold $10 \%$ perchloric acid, and $25 \mathrm{~mL}$ distilled water were added in this sample. After homogenizing the mixture at 10,000 rpm for 10 $\mathrm{sec}$ in a homogenizer (AM-Series), the homogenate was filtered using qualitative filter paper No. 2. After adding and completely mixing $5 \mathrm{~mL}$ of the filtrate solution and 5 $\mathrm{mL}$ of $0.02 \mathrm{M}$ TBA solution, the solution was allowed to stand for $16 \mathrm{~h}$ in a cool, dark place. The absorbance was measured at $529 \mathrm{~nm}$ using a Spectrophotometer (DU-650, Beckman, USA). 1,1,3,3,-Tetraethoxypropane (Sigma-Aldrich, USA) was used as standard for TBA assay. TBA values were expressed as milligram malonaldehyde (MA) per $1 \mathrm{~kg}$ sample (mg MA/kg), and the used standard curve equation was $\mathrm{y}=0.1975 \mathrm{x}-0.0011(\mathrm{r}=0.999)$, where $\mathrm{y}=$ absorbance for a given $\mathrm{x}$, the TBA value.

\section{Volatile basic nitrogen (VBN) value}

The VBN contents were measured by microdiffusion analysis (Short, 1954) using a Conway unit. For each sample, $10 \mathrm{~g}$ of sample was added to $90 \mathrm{~mL}$ of distilled water. After homogenizing at $10,000 \mathrm{rpm}$ for $30 \mathrm{~s}$ in a homogenizer (AM-Series), the homogenate was filtered using qualitative filter paper No. 2. Then, $1 \mathrm{~mL}$ of filtrate was placed in the outer compartment of a Conway unit, and $1 \mathrm{~mL}$ of $0.01 \mathrm{~N}$ boric acid and 3 drops of indicator $(0.066 \%$ methyl red $+0.066 \%$ bromocresol green $)$ were added in the inner compartment. Glycerin was applied as a gluing material, and the lid was closed. Then, $1 \mathrm{~mL}$ of $50 \% \mathrm{~K}_{2} \mathrm{CO}_{3}$ was injected in the outer compartment. After this, it was immediately sealed, and after horizontally stirring the vessel, the boric acid in the inner compartment 
was titrated with $0.02 \mathrm{~N} \mathrm{H}_{2} \mathrm{SO}_{4}$, after incubating at $37^{\circ} \mathrm{C}$ for $120 \mathrm{~min}$. The VBN value was expressed as $\mathrm{mg}(\mathrm{mg} \%)$ per $100 \mathrm{~g}$ sample using the following formula: $\mathrm{VBN}=$ $\{(\mathrm{a}-\mathrm{b}) \times \mathrm{F} \times 28.014 \times 100\} /$ amount of sample, where $\mathrm{a}$ is the amount of injected sulfuric acid $(\mathrm{mL}), \mathrm{b}$ is the amount of sulfuric acid injected in the blank $(\mathrm{mL})$, and $\mathrm{F}$ is the standardized index of $0.02 \mathrm{~N} \mathrm{H}_{2} \mathrm{SO}_{4}$. The constant 28.014 describes the amount required to consume $1 \mathrm{~mL}$ $0.02 \mathrm{~N} \mathrm{H}_{2} \mathrm{SO}_{4}$.

\section{Microbiological analysis}

For this analysis, $10 \mathrm{~g}$ samples were taken aseptically from each treatment, transferred to sterile plastic pouches, and homogenized with $90 \mathrm{~mL}$ of $0.1 \%$ peptone solution in a stomacher (400 Lab Blender, Seward, London, England) for $1.5 \mathrm{~min}$. Serial 10-fold dilution were prepared from each dilution by pouring $1 \mathrm{~mL}$ in fluid agar, and these were then incubated (APHA, 1992) for $48 \mathrm{~h}$ at $37^{\circ} \mathrm{C}$ by inoculating on plate count agar (PCA) medium. The results were expressed as log of colony forming units $(\mathrm{CFU}) / \mathrm{g}$.

\section{Statistical analysis}

Three replications of this study were performed and measured of all parameters were made in duplicate. The results from these tests were examined with an analysis of variance using the SAS program (2002), and its significance was verified at the level of 5\% using Duncan's multiple range test.

\section{Results and Discussion}

\section{Total polyphenol and total flavonoid contents of LBE}

Lipid components existing in food or biomembranes in vivo are oxidized by free radicals, which induce changes in food quality of food and cause aging in the human body. In order to prevent lipid oxidation, phenolic compounds, which are natural antioxidants, have been used (Nijveldt et al., 2001). Total polyphenol and total flavonoid contents of LBE are shown in Table 2. Total polyphenol and total flavonoids contents of LBE were 801.00 $\pm 9.24 \mathrm{mg}$ TAE$/ \mathrm{g}$ DW and 65.05 $\pm 2.43 \mathrm{mg} \mathrm{RE} / \mathrm{g}$, respectively. Flavonoids, a class of low-weight phenolics compound, are contained in the edible plant resources in quantity and have various functional biological effects, such as cardiovascular disease prevention, as well as anti-inflammatory, anti-allergic, antiviral, antioxidant, immune enhancement, and capillary potentiation activities (Kawaguchi et al., 1997). Thus, in this study, lemon balm, which con-
Table 2. Contents of total polyphenol and total flavonoids in lemon balm ethanol extract

\begin{tabular}{ccc}
\hline \hline Sample & $\begin{array}{c}\text { Total polyphenol content } \\
\text { (mg TAE/g DW) }\end{array}$ & $\begin{array}{c}\text { Total flavonoids content } \\
\text { (mg RE/g DW) }\end{array}$ \\
\hline LBE & $801.00 \pm 9.24^{1)}$ & $65.05 \pm 2.43$ \\
\hline
\end{tabular}

${ }^{1)}$ All values are expressed as mean $\pm \mathrm{SE}$ of triplicate determinations.

Table 3. Aantioxidative activities of lemon balm ethanol extract

\begin{tabular}{|c|c|c|}
\hline \multirow[b]{2}{*}{ Sample ${ }^{1)}$} & \multicolumn{2}{|c|}{ Antioxidative activity } \\
\hline & $\begin{array}{l}\text { DPPH radical scavenging } \\
\text { activity } \mathrm{IC}_{50}(\mu \mathrm{g} / \mathrm{mL})\end{array}$ & $\begin{array}{c}\left.\mathrm{IP}^{2}\right) \\
(\text { Antioxidant index) })^{3)}\end{array}$ \\
\hline LBE & $131.92 \pm 8.67^{4) \mathrm{a} 5)}$ & $13.22 \pm 0.41^{\mathrm{a}}(1.94)$ \\
\hline BHA & $94.16 \pm 6.47^{b}$ & $13.77 \pm 0.51^{\mathrm{a}}(2.00)$ \\
\hline BHT & $99.05 \pm 4.87^{\mathrm{b}}$ & $13.47 \pm 0.51^{\mathrm{a}}(1.97)$ \\
\hline $\begin{array}{c}\text { Ascorbic } \\
\text { acid }\end{array}$ & $42.34 \pm 2.16^{\mathrm{c}}$ & $15.32 \pm 0.25^{\mathrm{a}}(2.24)$ \\
\hline Control & - & $6.83 \pm 0.50^{\mathrm{b}}(1.00)$ \\
\hline
\end{tabular}

${ }^{1)} \mathrm{LBE}$ : $80 \%$ ethanol extract from lemon balm, BHA: butylated hydroxyanisole, BHT: butylated hydroxytoluene, Control: soybean oil without lemon balm ethanol extract.

${ }^{2)}$ Induction period (IP) of oil was determined by test of Rancimat at $110^{\circ} \mathrm{C}$.

${ }^{3)}$ Antioxidant index was expressed as IP of oil containing sample/ IP of soybean oil.

${ }^{4)}$ All values are expressed as mean $\pm \mathrm{SE}$ of triplicate determinations. ${ }^{\mathrm{a}-\mathrm{c}}$ Means with different letters in the same column are significantly different $(p<0.05)$ by Duncan's multiple range test.

tains abundant polyphenols and flavonoids, can be assumed to have natural antioxidant availability.

\section{Antioxidative activities of LBE}

Antioxidant activities of LBE by DPPH radical scavenging activity and by Rancimat assay are shown in Table 3. The $\mathrm{IC}_{50}$ values of DPPH radical scavenging of LBE, BHA, BHT, and ascorbic acid were 132, 94, 99, and 42 $\mu \mathrm{g} / \mathrm{mL}$, respectively. This result is in agreement with the finding of Dastmalchi et al. (2008) where they reported that the content of total polyphenol and the $\mathrm{IC}_{50}$ value of DPPH radical scavenging of LBE were $268 \mathrm{mg} \mathrm{GAE} / \mathrm{g}$ DW and $134 \mu \mathrm{g} / \mathrm{mL}$. These results are consistent with other reports that higher phenolic compound content leads to more DPPH radical scavenging activity (Kwak et al., 2005). The antioxidant index was measured by Rancimat assay in order to find out the level of inhibition of lipid oxidation by LBE, which showed an antioxidant index in $1.0 \mathrm{mg} / \mathrm{mL}$ of 1.94 . The antioxidant indices of BHA, BHT, and ascorbic acid in $1.0 \mathrm{mg} / \mathrm{mL}$ were $2.00,1.97$, and 2.24, respectively. The antioxidant index of LBE was also high, and this property was similar to those of BHA, BHT, and ascorbic acid. 
Proximate composition, caloric content, WHC and cooking loss of hamburger patties added with lemon balm powder

Proximate composition and caloric content of hamburger patties were not significantly different with the addition of lemon balm (data not shown). These results agreed with a study by Mohamed and Mansour (2012) that used natural plants such as rosemary and marjoram in the formulation of beef patties and reported no significant differences among the groups. There were no significant differences between the WHC and cooking loss of normal sample and treated samples (data not shown). In this study, the addition of lemon balm powder did not significantly affect the proximate composition, WHC, and cooking loss, perhaps due to the low amount of lemon balm powder used.

\section{Texture properties of hamburger patties added with lemon balm powder}

Results from the texture properties analysis of hamburger patties refrigerated for $15 \mathrm{~d}$ are shown in Table 4 . The hardness, cohesiveness, and springiness of hamburger patties tended to reduce with increased lemon balm powder, but there was no significant difference. For chewiness, the hamburger patties added with $1 \%$ lemon balm powder (L3 group) had the highest value compared to the other samples $(p<0.05)$. Lara et al. (2011) obtained similar results of increasing chewiness with the addition of lemon balm. Hwang et al. (1998) have reported that the changes in springiness and chewiness of the patty upon the addition of algae resulted from the binding capacity of the dietary fiber within the algae. Thus, chewiness was thought to have changed because the binding capacity of the patty upon the addition of lemon balm powder was increased.

\section{Sensory evaluation of hamburger patties added with lemon balm powder}

The sensory properties of hamburger patties containing lemon balm powder are shown in Table 5. For the color of cooked hamburger patty, the groups L1, L2, and L3 were evaluated higher than the normal group $(\mathrm{N})$, and as lemon balm addition increased, the results became significant, with the L3 and the positive control groups having the highest score. The color of the meat product significantly affects the sensory properties (Benedini et al., 2008). Generally, sensory properties of meat products with added herbs can be a disadvantage with regard to color. In this study, the color of patties became slightly dark red due to the addition of lemon balm powder, but it scored positively in preference evaluation. However, Berasategi et al. (2011) and Lara et al. (2011) reported that sensory evaluation for color did not reveal any significant difference between the control and the lemon balm treated samples. Springiness and juiciness were not significantly different among the groups. However, regarding flavor and total

Table 4. Textural properties of patties prepared with different levels of lemon balm powder

\begin{tabular}{|c|c|c|c|c|c|}
\hline \multirow{2}{*}{ Items } & \multicolumn{5}{|c|}{ " Treatments ${ }^{1)}$} \\
\hline & $\mathrm{N}$ & $\mathrm{C}$ & L1 & L2 & L3 \\
\hline Hardness (g) & $2054.00 \pm 97.86^{2)}$ & $2724.00 \pm 265.62$ & $2134.00 \pm 206.61$ & $2276.00 \pm 57.84$ & $2404.00 \pm 116.99$ \\
\hline Cohesiveness & $35.14 \pm 1.41$ & $39.00 \pm 3.14$ & $34.03 \pm 1.04$ & $35.27 \pm 1.49$ & $37.21 \pm 1.50$ \\
\hline Springiness & $53.84 \pm 3.98$ & $56.05 \pm 3.02$ & $54.51 \pm 0.49$ & $55.83 \pm 2.21$ & $54.10 \pm 2.01$ \\
\hline Chewiness (g) & $279.60 \pm 37.27^{b}$ & $281.31 \pm 35.64^{b}$ & $370.01 \pm 68.25^{\mathrm{ab}}$ & $397.21 \pm 49.49^{\mathrm{ab}}$ & $486.40 \pm 45.57^{\mathrm{a}}$ \\
\hline
\end{tabular}

${ }^{1)}$ See the legend of Table 1 .

${ }^{2)}$ All values are expressed as mean $\pm \mathrm{SE}$ of triplicate determinations.

${ }^{\mathrm{a}, \mathrm{b}}$ Means in the same row not sharing a common letter are significantly different $(p<0.05)$ by Duncan's multiple range test.

Table 5. Sensory evaluation of patties prepared with different levels of lemon balm powder

\begin{tabular}{cccccc}
\hline \hline Sensory & \multicolumn{4}{c}{ Treatments } \\
\cline { 2 - 6 } characteristics $^{2)}$ & $\mathrm{N}$ & $\mathrm{C}$ & $\mathrm{L} 1$ & $\mathrm{~L} 2$ & $\mathrm{~L} 3$ \\
\hline Color & $2.43 \pm 0.20^{3) \mathrm{c}}$ & $4.54 \pm 0.31^{\mathrm{a}}$ & $3.09 \pm 0.28^{\mathrm{bc}}$ & $3.93 \pm 0.23^{\mathrm{ab}}$ & $4.54 \pm 0.24^{\mathrm{a}}$ \\
Springiness & $3.50 \pm 0.19$ & $3.59 \pm 0.20$ & $3.66 \pm 0.18$ & $4.07 \pm 0.17$ & $3.84 \pm 0.28$ \\
Flavor & $3.57 \pm 0.20^{\mathrm{b}}$ & $3.59 \pm 0.17^{\mathrm{b}}$ & $4.03 \pm 0.25^{\mathrm{ab}}$ & $4.61 \pm 0.29^{\mathrm{a}}$ & $3.91 \pm 0.31^{\mathrm{ab}}$ \\
Juiciness & $3.61 \pm 0.26$ & $3.63 \pm 0.27$ & $3.87 \pm 0.15$ & $4.11 \pm 0.28$ & $3.93 \pm 0.25$ \\
Total acceptability & $3.31 \pm 0.20^{\mathrm{b}}$ & $3.41 \pm 0.48^{\mathrm{b}}$ & $4.11 \pm 0.17^{\mathrm{ab}}$ & $4.72 \pm 0.27^{\mathrm{a}}$ & $3.71 \pm 0.38^{\mathrm{ab}}$ \\
\hline
\end{tabular}

${ }^{1)}$ See the legend of Table 1 .

${ }^{2)} 1$ : dislike extremely, 3: neither like nor dislike, 5: like extremely.

${ }^{3)}$ All values are expressed as mean $\pm \mathrm{SE}$ of triplicate determinations.

${ }^{\mathrm{a}-\mathrm{c}}$ Means in the same row not sharing a common letter are significantly different $(p<0.05)$ by Duncan's multiple range test. 
acceptability, the patties in lemon balm-treated groups received higher scores than the normal $(\mathrm{N})$ and positive control (C) groups. In particular, the L2 group, in which $0.5 \%$ lemon balm powder was added, was most highly preferred, and the normal group $(\mathrm{N})$ was relatively lower preferred. Thus, the flavor and total acceptability of the patties with added lemon balm powder were highly favored because the fresh and sweet taste of lemon balm removed the unique flavor and aroma of beef and pork by acting positively on the patties. These results agree with Kong et al. (2010). They reported that the spice-treated patties, such as clove, rosemary, and cassia bark, had significantly lower discoloration, rancidity and off-flavour scores, but significantly higher overall acceptability scores than those of control sample, indicating that spices were able to improve the sensory quality of cooked patties.

\section{Changes in pH of patties added with lemon balm powder}

Table 6 shows the $\mathrm{pH}$ changes in uncooked hamburger patties added with lemon balm powder during refrigeration for $15 \mathrm{~d}$. The $\mathrm{pH}$ values immediately after preparing the normal group $(\mathrm{N})$, the positive control group $(\mathrm{C})$, and the treatment groups (L1, L2, and L3) were 6.03, 5.98, 5.91, 5.92, and 5.95, but they were 4.67, 4.56, 4.55, 4.58, and 4.52 , respectively, with $15 \mathrm{~d}$ of storage, decreasing over the storage period. The positive control group (C) and the treatment groups (L1, L2, and L3) had lower $\mathrm{pH}$ values compared to the normal group $(\mathrm{N})$, and the decreasing $\mathrm{pH}$ was not affected by the addition levels of lemon balm powder. Lara et al. (2011) found that $\mathrm{pH}$ values were significantly lower in pork patties with lemon balm throughout the storage period, which could be attributed to the fact the active compound in this extract is an acid (rosmaric acid in lemon balm, with a $\mathrm{pH}$ of 4.25). Similar trends in $\mathrm{pH}$ values were reported in studies by Kim (2011), in which pine needle extract was added to sausage. In addition, Langlosis and Kemp (1974) and Go- ddar et al. (1996) have reported that, overall, pH decreased as the storage period of the ground meat increased and originated with the generation of lactic acid, due to the growth of microorganisms.

\section{Changes in the TBA values of patties added with lemon balm powder}

The TBA values in uncooked hamburger patties added with lemon balm powder during refrigeration over a 15-d period are shown in Table 7. The TBA values of the positive control group (C) and groups added with lemon balm powder (L1, L2, and L3) were significantly lower than those in the normal group $(\mathrm{N})$ on the day of preparation, with a steady increase in TBA values during storage, but the groups added with lemon balm powder (L1, L2, and L3) had lower rates of increase compared to the normal group (N). On d 15 of storage, the normal group $(\mathrm{N})$ had the highest TBA value, $0.60 \mathrm{mg}$ malonaldehyde $/ \mathrm{kg}$, and the positive control group (C) and groups added with lemon balm powder (L1, L2, and L3) had significantly lower TBA values compared to the normal group $(\mathrm{N})$, with values of $0.35,0.56,0.47$, and $0.45 \mathrm{mg}$ malonaldehyde/kg, respectively. Also, lipid oxidation in the L3 group was not inhibited as much as the positive control group (C). Vuorela et al. (2005) have reported that they evaluated the degree of inhibition of lipid oxidation by measuring the amount of hexanal formed during storage by adding phenolic compounds extracted from various plants in the pork patty, and the more phenolic compounds that were added, the more the lipid oxidation was inhibited. In this study, phenolic compounds (Lamaison et al., 1990) such as flavonoids, terpenoic acid, carnosic acid, carnosol, and volatile oil, were high in lemon balm and inhibited the lipid oxidation in hamburger patties.

\section{Changes in VBN values of patties added with lemon balm powder}

The VBN contents in uncooked hamburger patties with

Table 6. pH changes of total aerobic counts for patties prepared with different levels of lemon balm powder during $15 \mathrm{~d}$ of storage at $5^{\circ} \mathrm{C}$

\begin{tabular}{|c|c|c|c|c|c|c|}
\hline & \multirow{2}{*}{ Storage time $(\mathrm{d})$} & \multicolumn{5}{|c|}{ "Treatments ${ }^{\mathrm{II}}$} \\
\hline & & $\mathrm{N}$ & $\mathrm{C}$ & L1 & $\mathrm{L} 2$ & L3 \\
\hline \multirow{4}{*}{$\mathrm{pH}$} & 0 & $6.03 \pm 0.01^{2) \mathrm{aA}}$ & $5.98 \pm 0.01^{\mathrm{bA}}$ & $5.91 \pm 0.01^{\mathrm{dA}}$ & $5.92 \pm 0.01^{\mathrm{dA}}$ & $5.95 \pm 0.01^{\mathrm{cA}}$ \\
\hline & 5 & $5.60 \pm 0.04^{\mathrm{aB}}$ & $5.31 \pm 0.03^{\mathrm{bB}}$ & $5.27 \pm 0.03^{\mathrm{bB}}$ & $5.23 \pm 0.02^{\mathrm{bcB}}$ & $5.13 \pm 0.03^{\mathrm{cB}}$ \\
\hline & 10 & $4.74 \pm 0.01^{\mathrm{aC}}$ & $4.64 \pm 0.01^{\mathrm{bC}}$ & $4.62 \pm 0.01^{b c C}$ & $4.63 \pm 0.01^{\mathrm{bcC}}$ & $4.60 \pm 0.01^{\mathrm{cC}}$ \\
\hline & 15 & $4.67 \pm 0.01^{\mathrm{aC}}$ & $4.56 \pm 0.01^{\mathrm{bcC}}$ & $4.55 \pm 0.01^{\mathrm{cD}}$ & $4.58 \pm 0.01^{\mathrm{bD}}$ & $4.52 \pm 0.01^{\mathrm{dD}}$ \\
\hline
\end{tabular}

\footnotetext{
${ }^{1)}$ See the legend of Table 1.

${ }^{2)}$ All values are expressed as mean $\pm \mathrm{SE}$ of triplicate determinations.

${ }^{\mathrm{a}-\mathrm{d}}$ Means in the same row not sharing a common letter are significantly different $(p<0.05)$ by Duncan's multiple range test.

${ }^{\mathrm{A}-\mathrm{D}}$ Means in the same column not sharing a common letter are significantly different $(p<0.05)$ by Duncan's multiple range test.
} 
Table 7. Changes of thiobarbituric acid (TBA) for patties prepared with different levels of lemon balm powder during $15 \mathrm{~d}$ of storage at $5^{\circ} \mathrm{C}$

\begin{tabular}{ccccccc}
\hline \hline & \multirow{2}{*}{ Storage time $(\mathrm{d})$} & \multicolumn{3}{c}{ Treatments $^{\mathrm{l})}$} \\
\cline { 3 - 7 } & & $\mathrm{N}$ & $\mathrm{C}$ & $\mathrm{L} 1$ & $\mathrm{~L} 2$ & $\mathrm{~L} 3$ \\
\hline & 0 & $0.29 \pm 0.01^{2 \mathrm{aD}}$ & $0.18 \pm 0.01^{\mathrm{eD}}$ & $0.24 \pm 0.01^{\mathrm{cC}}$ & $0.26 \pm 0.01^{\mathrm{bD}}$ & $0.21 \pm 0.01^{\mathrm{dD}}$ \\
TBA & 5 & $0.40 \pm 0.01^{\mathrm{aC}}$ & $0.26 \pm 0.01^{\mathrm{cC}}$ & $0.34 \pm 0.01^{\mathrm{bB}}$ & $0.27 \pm 0.01^{\mathrm{cC}}$ & $0.26 \pm 0.02^{\mathrm{cC}}$ \\
$(\mathrm{mg} \mathrm{MA} / \mathrm{kg})$ & 10 & $0.46 \pm 0.01^{\mathrm{aB}}$ & $0.32 \pm 0.01^{\mathrm{cAB}}$ & $0.33 \pm 0.01^{\mathrm{cB}}$ & $0.39 \pm 0.01^{\mathrm{bB}}$ & $0.30 \pm 0.01^{\mathrm{cB}}$ \\
& 15 & $0.60 \pm 0.01^{\mathrm{aA}}$ & $0.35 \pm 0.01^{\mathrm{eA}}$ & $0.56 \pm 0.01^{\mathrm{bA}}$ & $0.47 \pm 0.01^{\mathrm{cA}}$ & $0.45 \pm 0.01^{\mathrm{dA}}$ \\
\hline
\end{tabular}

${ }^{1)}$ See the legend of Table 1 .

${ }^{2)}$ All values are expressed as mean $\pm \mathrm{SE}$ of triplicate determinations.

${ }^{\mathrm{a}-\mathrm{d}}$ Means in the same row not sharing a common letter are significantly different $(p<0.05)$ by Duncan's multiple range test.

${ }^{\mathrm{A}-\mathrm{D}}$ Means in the same column not sharing a common letter are significantly different $(p<0.05)$ by Duncan's multiple range test.

Table 8. Changes of volatile basic nitrogen (VBN) for patties prepared with different levels of lemon balm powder during $15 \mathrm{~d}$ of storage at $5^{\circ} \mathrm{C}$

\begin{tabular}{ccccccc}
\hline \hline & \multirow{2}{*}{ Storage time $(\mathrm{d})$} & \multicolumn{5}{c}{ Treatments $^{\mathrm{I}}$} \\
\cline { 3 - 7 } & & $\mathrm{N}$ & $\mathrm{C}$ & $\mathrm{L} 1$ & $\mathrm{~L} 2$ & $\mathrm{~L}$ \\
\hline & 0 & $5.95 \pm 0.09^{2) \mathrm{abD}}$ & $5.31 \pm 0.09^{\mathrm{bD}}$ & $6.59 \pm 0.27^{\mathrm{aC}}$ & $6.68 \pm 0.37^{\mathrm{aC}}$ & $6.59 \pm 0.16^{\mathrm{aD}}$ \\
$\mathrm{VBN}$ & 5 & $10.57 \pm 0.32^{\mathrm{abC}}$ & $9.47 \pm 0.16^{\mathrm{bC}}$ & $13.59 \pm 1.35^{\mathrm{aB}}$ & $10.84 \pm 1.35^{\mathrm{abB}}$ & $9.38 \pm 0.51^{\mathrm{bC}}$ \\
$(\mathrm{mg} \%)$ & 10 & $15.33 \pm 0.64^{\mathrm{aB}}$ & $11.67 \pm 0.27^{\mathrm{bB}}$ & $14.87 \pm 0.66^{\mathrm{aAB}}$ & $13.59 \pm 0.42^{\mathrm{aB}}$ & $11.39 \pm 0.16^{\mathrm{bB}}$ \\
& 15 & $17.80 \pm 0.24^{\mathrm{aA}}$ & $15.05 \pm 0.48^{\mathrm{bA}}$ & $17.62 \pm 0.09^{\mathrm{aA}}$ & $17.25 \pm 0.33^{\mathrm{aA}}$ & $15.76 \pm 0.27^{\mathrm{bA}}$ \\
\hline
\end{tabular}

${ }^{1)}$ See the legend of Table 1 .

${ }^{2)}$ All values are expressed as mean $\pm \mathrm{SE}$ of triplicate determinations.

${ }^{\mathrm{a}-\mathrm{d}}$ Means in the same row not sharing a common letter are significantly different $(p<0.05)$ by Duncan's multiple range test.

${ }^{\text {A-D }}$ Means in the same column not sharing a common letter are significantly different $(p<0.05)$ by Duncan's multiple range test.

lemon balm powder that were refrigerated for $15 \mathrm{~d}$ are shown in Table 8. The VBN content on the day of preparation was $5.3-6.68 \mathrm{mg} \%$, but increased to $15.05-17.80$ $\mathrm{mg} \%$ on $\mathrm{d} 15$ of storage. The L3 group, except for immediately after manufacturing with $5 \mathrm{~d}$ of storage, had significantly lower values compared with the normal group (N) and had the VBN content similar to the positive control group (C). The VBN content of raw meat and packed meat is regulated at $20 \mathrm{mg} \%$ or less in the Korea Food Sanitation Act (2002). In this study, the VBN content of hamburger patties during storage period was maintained at $20 \mathrm{mg} \%$ or less. There was no corruption of protein, and freshness was maintained. The L3 group could inhibit the increase in VBN content compared to the normal group (N) due to antioxidant and antibacterial effects (Gruenwalkd et al., 1999; Sweetman, 2002). Thus, the addition of lemon balm powder will be effective in maintaining meat quality by effectively inhibiting the creation of VBN.

\section{Changes in total aerobic bacteria added with lemon balm powder}

The total plate counts in uncooked hamburger patties added with lemon balm powder during refrigeration over a 15-d period are shown in Table 9. In general, total plate counts significantly increased in linear fashion in all patties. However, on d 10 and 15, the L3 group had signifi- cantly lower total plate counts compared to the normal group $(\mathrm{N})$ and had a similar level to the positive control group (C). These groups tended to show inhibition of the growth of microbes, with approximately 0.5-1 log levels lower than the normal group $(\mathrm{N})$ upon the addition of $1 \%$ lemon balm powder or more. In general, when the total aerobic bacteria counts in meat reached 7-8 Log CFU/g, corruption and off-odor occurred (Egan et al., 1980). Analyzing the stored hamburger patties after $15 \mathrm{~d}$, the normal (N), L1, and L2 groups had values of 7.69, 7.40, and 7.18, respectively, verifying that deterioration was occurring. Because the positive control group (C) and the L3 group showed inhibition of microbial proliferation, these groups were safe from bacteria during storage. The L3 group had inhibited proliferation of the total aerobic bacteria compared to the normal group $(\mathrm{N})$ due to antiseptic action and antibacterial effects (Gruenwalkd et al., 1999; Sweetman, 2002) of lemon balm powder. Therefore, the addition of lemon balm powder extended the storage period by inhibiting corruption and deterioration by microorganisms.

\section{Conclusion}

The aims of this study were to examine the antioxidant properties of lemon balm in order to evaluate the potential use of lemon balm as a functional food material and 
Table 9. Changes of total aerobic counts (TPC) for patties prepared with different levels of lemon balm powder during $15 \mathrm{~d}$ of storage at $5^{\circ} \mathrm{C}$

\begin{tabular}{|c|c|c|c|c|c|c|}
\hline & \multirow{2}{*}{ Storage time $(\mathrm{d})$} & \multicolumn{5}{|c|}{ Treatments $^{1)}$} \\
\hline & & $\mathrm{N}$ & $\mathrm{C}$ & L1 & L2 & L3 \\
\hline \multirow{4}{*}{ Log CFU/g } & 0 & $3.93 \pm 0.09^{2) D}$ & $4.01 \pm 0.01^{\mathrm{D}}$ & $3.94 \pm 0.08^{\mathrm{D}}$ & $3.92 \pm 0.01^{\mathrm{D}}$ & $4.03 \pm 0.02^{\mathrm{D}}$ \\
\hline & 5 & $5.39 \pm 0.01^{\mathrm{aC}}$ & $4.95 \pm 0.02^{\mathrm{cC}}$ & $5.34 \pm 0.01^{\mathrm{aC}}$ & $5.02 \pm 0.02^{\mathrm{bC}}$ & $5.05 \pm 0.02^{\mathrm{bC}}$ \\
\hline & 10 & $6.53 \pm 0.06^{\mathrm{aB}}$ & $5.90 \pm 0.01^{\mathrm{cB}}$ & $6.29 \pm 0.11^{\mathrm{abB}}$ & $6.16 \pm 0.07^{\mathrm{bcB}}$ & $5.93 \pm 0.05^{\mathrm{cB}}$ \\
\hline & 15 & $7.69 \pm 0.21^{\mathrm{aA}}$ & $6.40 \pm 0.12^{\mathrm{bA}}$ & $7.40 \pm 0.01^{\mathrm{aA}}$ & $7.18 \pm 0.01^{\mathrm{aA}}$ & $6.48 \pm 0.01^{\mathrm{bA}}$ \\
\hline
\end{tabular}

${ }^{1)}$ See the legend of Table 1 .

${ }^{2)}$ All values are expressed as mean $\pm \mathrm{SE}$ of triplicate determinations.

${ }^{\text {a-d }}$ Means in the same row not sharing a common letter are significantly different $(p<0.05)$ by Duncan's multiple range test.

${ }^{\text {A-D }}$ Means in the same column not sharing a common letter are significantly different $(p<0.05)$ by Duncan's multiple range test.

to investigate the antioxidant properties of lemon balm in ground hamburger patties stored for $15 \mathrm{~d}$ at $4^{\circ} \mathrm{C}$. The high total polyphenol and total flavonoids contents, and high antioxidant activity were exhibited in the lemon balm. The patties made with addition lemon balm had significantly lower total aerobic bacteria counts, TBA and VBN values compared to the normal sample. Lemon balm-treated patties had also significantly higher flavor and total acceptability scores than those of the normal sample. In conclusion, lemon balm has been indicated to protect against lipid oxidation and to improve the sensory attributes of ground hamburger patties. Therefore lemon balm is a useful natural antioxidant with strong potential to be used in meat products.

\section{References}

1. AOAC (1990) Official methods of analysis. 15th ed. Association of Official Analytical Chemists, Washington, DC, USA, p 788.

2. APHA (1992) Compendium of methods for the microbiological examination of foods. American Public Health Association, Washington, DC, USA.

3. Barnen, A. L. (1975) Toxicological and biochemistry of BHA and BHT. J. Am. Oil Chem. Soc. 52, 59-63.

4. Benedini, R., Raja, V., and Parolari, G. (2008) Zinc-protoporphyrin IX promoting activity in pork muscle. Food Sci. Technol. 41, 1160-1166.

5. Berasategi, I., Legarra, S., Garacía-Íñiguez de Ciriano, M., Rehecho, S., Calvo, M. I., Cavero, R. Y., Navarro-Blasco, Í., Ansorena, D., and Astiasarán, I. (2011) "High in omega-3 fatty acids" bologna-type sausage stabilized with an aqueous-ethanol extract of Melissa officinalis. Meat Sci. 88, 705-711.

6. Blois, M. S. (1958) Antioxidant determinations by the use of a stable free radical. Nature 181, 1199-1203.

7. Chae, S. K., Kang, G. S., Ma, S. J., Bang, K. W., Oh, M. W., and Oh, S. H. (2002) Standard food analysis. Jigu-moonwha Sa. p. 381-382.

8. Choi, P. S., Kim, H. S., and Chin, K. B. (2013) Antioxidant activities of water of methanol extract from cherry (Prunus yedoensis) and its utilization to the pork patties. Korean $J$. Food Sci. An. 33, 268-275.

9. Choi, Y. S., Choi, J. H., Kim, H. Y., Kim, H. W., Lee, M. A., Chung, H. J., Lee, S. K., and Kim, C. J. (2011) Effect of lotus (Nelumbo nucifera) leaf power on the quality characteristics of chiken patties in refrigerated storage. Korean J. Food An. 31, 9-18.

10. Cross, H. R., Berry, B. W., and Wells, L. H. (1980) Effect of fat level and source on the chemical, sensory and cooking properties of ground beef patties. J. Food Sci. 45, 870-875.

11. Dastmalchi, K., Damien Dorman, H. J., Oinonen, P. P., Darwis, Y., Laakso, I., and Hiltunen, R (2008) Chemical composition and in vitro antooxidative activity of a lemon balm (Melissa officinalis L.) extract. LWT-Food Sci. Technol. 41, 391400.

12. Egan, A. F., Ford, A. L., and Shay, B. J. (1980) A comparison of Brochothrix thermosphacta and Lactobacilli as a spoilage organism of vacuum packaged sliced luncheon meats. J. Food Sci. 45, 1745-1748.

13. El-Alim, S. L. A., Lugasi, A., Hóvari, J., and Dworschák, E. (1999) Culinary herbs inhibit lipid oxidation in raw and cooked minced meat patties during storage. J. Sci. Food Agric. 72, 277-285.

14. Folin, O. and Denis, W. (1912) On phosphotungastic phosphomolybdic compounds as color regents. J. Biol. Chem. 12, 239-249.

15. Goddar, B. L., Mikel, W. B., Conner, D. E., and Jones, E. R. (1996) Use of organic acids to improve the chemical, physi$\mathrm{cal}$, and microbial attributes of beef strip loins stored at $-1^{\circ} \mathrm{C}$ for 112 days. J. Food Prot. 59, 849-853.

16. Garacía-Íñiguez de Ciriano, M., Rehecho, S., Calvo, M. I., Cavero, R Y., Navarro, Í., Astiasarán, I., and Ansorena, D. (2010) Effect of lyophilized water extracts of Melissa officinalis on the stability of algae and linseed oil-in water emulsiom to be used as a functional ingredients in meat products. Meat Sci. 85, 373-377.

17. Gruenwalkd, J., Brendler, T., Jaenicke, C., and Fleming, T. (2000) PDR for herbal medicines 2nd ed. Medical Economics Company, Montvale, NJ, USA. p. 461-463.

18. Hernández-Hernández, E., Ponce-Alquicira, E., JaramilloFlores, M. E., and Guerrero Legarreta, I. (2009) Antioxidant effect of rosemary (Rosemarinus officinalis L.) and orego (Origanum vulgare L.) extracts on TBARS and colour of 
model raw pork batters. Meat Sci. 81, 410-417.

19. Hwang, J. K., Hong, S. I., Kim, C. T., Choi, M. J., and Kim, Y. J. (1998) Quality changes in meat patties by addition of sea mustard paste. J. Korean Soc. Food Sci. Nutr. 27, 477-481.

20. Jang, K. H., Park, H. W., and Lee, D. J. (2011) Evaluation of antioxidant, anticancer and tyrosinase inhibition activities in labiates herb plants. Korean J. Intl. Agri. 23, 81-88.

21. Joo, K. J. and Kim, J. J. (2002) Oxidative stability and flavor compounds of sesame oils blended with vegetable oils. Korean J. Food Sci. Technol. 34, 499-502.

22. Jung, I. C., Moon, Y. H., and Kang, S. J. (2004) Storage stability of pork patty with mugwort powder. J. Life Sci. 14, 198203.

23. Kawaguchi, K., Mizuno, T., Aida, K., and Uchino, K. (1997) Hesperidin as an inhibitor of lipases from porcine pancreas and pseudomonas. Biosci. Biotech. Biochem. 61, 102-104.

24. Khalil, A. H. (2000) Quality characteristics of low-fat beef patties formulated with modified corn starch and water. Food Chem. 68, 61-68.

25. Kim, Y. J. (2011) Effects of addition of pine needle extracts in different forms on the antioxidant and residual nitrite contents of emulsified sausages during cold storage. Korean $J$. Food Sci. An. 31, 74-80.

26. Kong, B., Zhang, H., and Xiong, Y. (2010) Antioxidant activity of spice extracts in a liposome system and in cooked pork patties and the possible mode of action. Meat Sci. 85, 772778.

27. Korean Food \& Drug Administration (2002) Food Code 2002. Moonyoungsa. Seoul. p. 220.

28. Kwak, C. S., Kim, S. A., and Lee, M. S. (2005) The correlation of antioxidative effects of 5 Korean common edible seaweeds and total polyphenol content. J. Korean Soc. Food Sci. Nutr. 34, 1143-1150.

29. Laakkonen, E., Wellington, G. H., and Skerbon, J. W. (1970) Low temperature longtime heating of bovine. I. Changes in tenderness, water binding capacity, $\mathrm{pH}$ and amount of watersoluble component. J. Food Sci. 35, 175-177.

30. Lamaison, J. L., Petitjean-Freytet, C., and Carnat, A. (1990) Rosmarinic acid, total hydroxycinnamic derivatives and antioxidant activity of Apiaceae, Borraginaceae and Lamiceae medicinals. Ann. Pharm. Fr. 48, 103-108.

31. Langlosis, B. E. and Kemp, J. D. (1974) Microflors of fresh and dry-cured hams and affected by fresh ham storage. $J$. Anim. Sci. 38, 525-532.

32. Lara, M. S., Cutierrez, J. I., Timon, M., and Andres, A. I. (2011) Evaluation of two natural extracts (Rosmarinus officinalis L. and Melissa officinalis L.) as antioxidants in cooked patties packed in MAP. Meat Sci. 88, 481-488.

33. Lee, S. H. and Cho, S. H. (2012) Characteristics of hamburger patties containing yam powder. Korean J. Food Cookery Sci. 28, 781-787.

34. McCarthy, T. L., Kerry, J. P., Kerry, J. F., Lynch, P. B., and Buckley, D. J. (2001) Assessment of the antioxidant potential of natural food and plant extracts in fresh and previously frozen pork patties. Meat Sci. 57, 177-184.
35. Miller, M. F., Davis, G. W., Williams, A. C., Ramsey Jr, C. B., and Galyean, R. D. (1987) Palatability and appearance traits of beef/pork meat patties. J. Food Sci. 52, 886-889.

36. Mohamed, H. M. H. and Mansour, H. A. (2012) Incorporating essential oils of marjoram and rosemary in the formulation of beef patties manufactured with mechanically deboned poultry meat to improve the lupid stability and sensory attributes. LWT-Food Sci. Technol. 45, 79-87.

37. Murphy, A., Kerry, I. P., Buckley, J., and Gray, I. (1998) The antioxidative properties of rosemary oleoresin and inhibition of off-flavours in precooked roast beef slices. J. Sci. Food Agric. 77, 235-243.

38. Mukai, F. H. and Goldstein, B. D. (1976) Mutagenicity of malonaldehyde, a decomposition product of peroxidized polyunsaturated fatty acids. Science 191, 868-869.

39. Nijveldt, R. J., van Nood, E., van Hoorn, D. E., Boelens, P. G., van Norren, K., and van Leeuwen, P. A. (2001) Flavonoids: a review of probable mechanisms of action and potential applications. Am. J. Clin. Nutr. 74, 418-425.

40. Oh, H. K. and Lim, H. S. (2011) Quality characteristics of the hamburger patties with bamboo (Sasa borealis) leaf extract with/without cooked rice. Korean J. Food Sci. An. 30, 833841.

41. Park, K. S., Park, H. S., Choi, Y. J., Moon, Y. H., Lee, K. S., Kim, M. J., and Jung, I. C. (2011) Quality change of pork patty containing lotus (Nelumbo nucifera) leaf and root powder during refrigerated storage. J. Life Sci. 21, 1732-1739.

42. Shamberger, R. J., Andreone, T. L., and Willis, C. E. (1974) Antioxidants and cancer. IV. Initiating activity of malonaldehyde as a carcinogen. J. Nat'l. Cancer Inst. 53, 1771-1775.

43. Shamberger, R. J., Shamberger, B. A., and Willis, C. E. (1977) Malonaldehyde content of food. J. Nutr. 107, 1404-1409.

44. Short, E. I. (1954) The estimation of total nitrogen using the Conway micro-diffusion cell. J. Clin. Pathol. 7, 81-83.

45. Song, H. I., Moon, G. I., Moon, Y. H., and Jung, I. C. (2000) Quality and storage stability of hamburger during low temperature storage. Korean J. Food Sci. An. 20, 72-78.

46. Sweetman, S. C. (2002) Martindale: the complete drug reference 33rd ed. Pharmaceutical Press, London, UK. p. 1632.

47. Tichivangana, J. Z. and Morrissey, P. A. (1985) Metmyoglobin and inorganic metals as prooxidants in raw and cooked muscle system. Meat Sci. 15, 107-116.

48. Vuorela, S., Salminen, H., Mäkelä, M., Kivikari, R., Karonen, M., and Heinonen, M. (2005) Effect of plant phenolics on protein and lipid oxidation in cooked pork meat patties. $J$. Agr. Food Chem. 53, 8492-8497.

49. Witte, V. C., Krause, G. F., and Baile, M. E. (1970) A new extraction method for determining 2-thiobarbituric acid values of pork and beef during storage. J. Food Sci. 35, 582-587.

50. Yang, H. J., Kim, E. H., Park, J. O., Kim, J. E., and Park, S. N. (2009) Antioxidative activity and component analysis of fermented Malissa officinalis extracts. J. Soc. Cosmet. Scientists Korea 35, 47-55.

(Received 2014.5.30/Revised 2014.7.29/Accepted 2014.8.4) 